\title{
Leading sectors and structural dynamics: an Input-Output analysis contrasting the BRICs growth paths
}

\author{
Guilherme Riccioppo Magacho* \\ Nelson Marconi† \\ Igor Rochał
}

\begin{abstract}
With the aim of analyzing the different growth paths of the BRIC countries in recent decades and their long-term consequences, this study assessed the potential of different economic sectors (primary, manufacturing and services) to promote economic growth. Input-output tables were used to calculate each sector's output multipliers, RasmussenHirschman backward and forward linkage indexes, and pure normalized backward and forward linkage indexes with the aim of assessing which sectoral orientation has a higher potential to stimulate the economy as a whole. The results show that manufacturing is the sector where the multipliers are the highest, while they are the lowest in agriculture and mineral commodities. The findings corroborate the hypothesis that having a dynamic manufacturing sector is essential to promote economic growth. Moreover, the results show that forward linkages are larger than backward linkages for services and that modern services present slightly larger forward linkages than those observed for traditional services.
\end{abstract}

Keywords: Economic growth, BRICs, Input-output analysis, Sectoral specialization, Growth of Developing Countries, Patterns of Development.

JEL Classification: $\mathrm{O} 14, \mathrm{O} 21$

\footnotetext{
"Visiting Professor at Federal University of ABC. (UFABC). E-mail: guilherme.magacho@ufabc.edu.br + Assistant Professor at São Paulo School of Business Administration of Fundação Getulio Vargas. E-mail: nelson.marconi@fgv.br

‡ Economic Director at ABDIB. E-mail: igor@abdib.org.br
} 


\section{Introduction}

In the early 2000s, the term BRICs (Brazil, Russia, India and China) emerged to denote a group of four large countries that could attain rapid economic growth due to their potential market and production. Suddenly, the markets focused on the possible earnings in those countries and on their economic indicators

${ }^{1}$. In fact, they presented satisfactory growth rates for exports and income, and they became attractive to investors. Most - with the exception of China - used their comparative advantages, increasing world demand and rising prices for raw materials and primary goods (including the demand from China); they increased their exports of primary goods (and services, in India) and believed that doing so would increase domestic production and growth, by virtue of the effects on demand and the linkages generated by the greater production of those goods. In the Brazilian case, for example, commodities played a key role in the economy's dynamism, which was highly associated with Asian demand, notably that of China (Prates, 2006; Rocha, 2011).

This scenario reflected intense economic growth in those countries in the 2000s, especially before the 2008/09 financial crises and, given the importance of this growth to policy-making, favored a vast range of interpretations that sought to determine the factors and instruments that triggered this process. Economic growth, led by exports of primary products, especially commodities, and the role of services in economic development assumed prominent positions in interpretations of the growth experienced during that period. Some economists suggested that expansion based on the production and export of commodities does not have a negative effect on the economy. In addition to being capable of generating income in export sectors, primary sectors have indirect effects on other productive chains. Primary sectors also have the capacity to generate income beyond consumption that could resupply domestic production and related services (Schultz, 1964; Lipton, 1968; Chayanov, 1966; Davis, 1995; Mikesell, 1997). This line of thought has constantly sought to refute the necessity of industrial and foreign trade policies. It notes that state interventionism in favor of industrial sectors would promote an "artificial" industrialization not compatible with international patterns based in a competitive free market.

Another line of thinking has emphasized the role of services in economic growth, which is summarized in the OECD Growth in Service report (OECD, 2005). In this study, a vast range of arguments involve policies to enhance the

\footnotetext{
${ }^{1}$ South Africa joined the group later. 
potential of services to foster employment, productivity and innovation, especially in the economic transition from middle to high income per capita. These arguments assert that services are elastic in relation to income, and hence the share of services in demand grow as income increases (Engel's law). Servitization, which is defined as the expansion of more sophisticated and high-value-added service activities related to manufacturing, such as marketing, design, software and logistics (Evangelista et al., 2014; McKinsey \& Company, 2012; Lodefalk, 2013; Nordås and Kim, 2013), is one such possible effect. Outsourcing non-core activities originally produced in manufacturing industries is also an explanation for the increase in services in countries' GDPs (Evangelista et al., 2014; McKinsey \& Company, 2012). In this case, the increase in services is due only to the substitution of sectors before being classified as manufacturing. Therefore, it is important to distinguish this outsourcing process from the servitization discussed above. While the outsourcing process is associated with low productivity activities, the service sectors stimulated by servitization have higher technological content, and they are more sophisticated, demanding qualified workers and promoting more value-added per capita. In this sense, it is crucial to evaluate whether different types of services are produced and if this difference directly impacts other sectors' activity. ${ }^{2}$

However, several studies have attempted to demonstrate the limitations in promoting countries' productive and foreign trade structures assuming that primary or service sectors are the leading sectors. Both classic Kaldorian interpretations (Kaldor, 1966, 1981; Cornwall, 1977, Thirlwall and Hussein, 1982; McCombie and Thirlwall, 1994a, 1994b; Verdoorn, 1949; Thirlwall, 2004; Dasgupta and Singh, 2005, 2007; Dixon and Thirlwall, 1975; Moreno-Brid, 2003) and those based on the structuralist approach of Latin American thought (Prebisch 2000; Singer, 1950; Furtado, 2000; Tavares, 1998) have emphasized the limitations in promoting economic development based on a productive and trade structure of low-value-added products.

The main argument of those who do not support economic growth strategies based on primary product exports or services is that manufacturing is the main engine of economic development. ${ }^{3}$ Authors such as Rosenstein-Rodan (1943),

\footnotetext{
2 The definitions of modern and traditional services are based on their technological content, productivity and value added. Modern services are those related to financial intermediation; information and communication; and professional, scientific and technical activities. Traditional services are those related to wholesale and retail trade, transportation and storage, accommodation and food service, real estate, public administration, education, and social services. Although there is no clear definition of these activities, in this paper, we follow that developed by Eichengreen and Gupta (2012) and Ghani et al. (2011), with some minor changes to adjust to the data available.

${ }^{3}$ Rodrik (2007), Szirmai (2012) and Fagerberg and Verspagen (1999) support the same arguments.
} 
Prebisch (2000), Lewis (1969), Rostow (1960) and Furtado (2000) were some of the first intellectuals to emphasize the importance of manufacturing to economic development. According to them, development is essentially a process of structural change. Broadly speaking, sustained economic growth is associated with the capacity to diversify the structure of domestic production, i.e., generate new activities to expand the possibilities of production, linkages and higher-value-added goods by providing incentives for manufacturing. According to Kaldor (1989), economic growth is brought about by shifting from productive sectors with decreasing returns to those with increasing returns. This shift creates dynamic economies of scale. Kaldor presented seminal evidences that the manufacturing sector has the greatest capacity to do so, and therefore, its expansion plays a key role in promoting sustainable growth in the long term and the consequent modernization and diversification of the production structure.

Along the same lines, Chenery et al. (1986) argued that economic development is triggered by productive transformations induced by increasing demand for product diversity and technological progress. Such transformations would also lead to more productive use of inputs and increased productivity. The industrialization process feeds itself and diversifies the production structure. Such changes in demand resulting from growth entail a dynamic element that transforms the production structure. They lead to a shift in the composition of production and thus in supply, requiring new investments, which ultimately lead to technological improvements and further stimulate demand. In a more advanced stage of development, demand would be driven not only by manufactured goods but also by modern services reflecting a new shift in the productive structure.

Based on a distinct approach, Sachs and Warner (2001) also argued against economic growth based on primary product exports. The authors emphasized what they called the "natural resource curse", in which resource-abundant countries tended to experience lower income growth than resource-poor countries. Positive wealth effects from the natural resource sector drive up non-traded prices, which squeezes profits in traded activities, such as manufacturing, that use those non-traded products as inputs. The decline in manufacturing then has ramifications that cause the growth process to grind to a halt (Sachs and Warner, 2001, p.833). This argument was discussed by many authors, such as Brunnschweiler (2008) and Bulte et al. (2005), and the main findings are that that natural resources are not necessarily a curse but are not always a blessing. Daniele (2011), for example, showed that it is not that the abundance of natural resources constrains countries' 
development but rather that the dependence on these resources (measured as the share of total exports) tends to be associated with lower development.

Along the same lines, another school of thought, derived from structuralism and referred to as developmentalism, is particularly supported by theorists who observe the negative effects of currency appreciation in the manufacturing sector caused by exports of commodities, a process known as the "Dutch Disease" (Palma, 2005; Bresser-Pereira, 2008). In this dynamic, the existence of comparative advantages in natural resources significantly boosts exports of low-value-added products, such as commodities, resulting in a major inflow of dollars into the domestic economy and in the appreciation of the domestic currency in real terms. In a scenario of rising commodity prices, the implications would be even more serious for domestic industry because the competitiveness of higher-value-added products would be reduced, possibly triggering a process of "deindustrialization" of the economy. In this case, the productive structure moves toward primary and non-tradable services, which are usually traditional services, as argued by Corden and Nearly (1982).

Hirschman (1958) was one of the first authors to analyse the inter-sectoral externalities that results from a stimulus to a given sector. The author argued that a development strategy should focus on ensuring investments in sectors that can generate backward and forward linkages, i.e., stimulating the production of inputs used in the production process, generating economies of scale within the sector, or outputs that can be used as inputs in other sectors, also leading to productivity gains and cost savings for sectors in the later stages of the production chain. The analysis of the linkages allows evaluating the capacity of growth strategies based on primary exports, manufacturing or services in stimulating production in other sectors and, thereafter, their success. ${ }^{4}$

Thus, with the aim of evaluating the dynamic effects of a growth process driven by commodity exports, such as that adopted by Brazil and Russia, and by services exports, such as those of India in recent years, this paper compares possible production linkages that can be created by stimulating these sectors, in which those countries enjoy comparative advantages in production, with those that could be generated by providing incentives for manufacturing or services. This paper also assesses whether this process can be successful from the point of view of production diversification and, consequently, contribute to fostering economic

${ }^{4}$ We will also analyze both linkages for traditional services with low-value-added, which the early theorists discussed, and for modern services, which are related to the process of income growth and servitization that is currently occurring in the production chains. 
growth. This is the case for China. The BRIC countries have had three different levers for growth in recent years, and we will compare the results for both. For this purpose, this paper will adopt analyses based on input-output tables to empirically determine the capacity of primary sectors and their exports and also of services to leverage growth in those economies vis-à-vis manufacturing. Based on the theoretical discussion above, the idea is to assess whether exports of primary goods and services can generate production linkages as argued by economists who support the adoption of this development model.

The paper is divided into five sections, including this introduction and concluding remarks. The following section provides a brief analysis of the main features of the post-1990s BRICs' economic performance. Next, the input-output methodology that is used in this analysis is presented. Then, production multipliers, Hirschman-Rasmussen backward and forward linkage indexes, and pure normalized backward and forward linkage indexes comprising primary and service sectors and the manufacturing industry are calculated, and the results for the BRIC countries are compared. Finally, the conclusion will discuss, based on the results for the estimated indexes, the potential to stimulate growth from distinct orientations in trade and production composition.

\section{The BRICs' Economic Performance}

The initial classification of the BRIC countries coined by Jim O'Neill of Goldman Sachs in a 2001 article covered only Brazil, Russia, India and China. Based on this acronym, a vast range of research sought to provide explanations for these countries' dynamism through various economic and demographic indicators that suggested that these countries would have the greatest potential for growth in the first half of the 21st century. These indicators include but are not limited to the BRICs' increasing share in the world Gross Domestic Product (GDP) and world exports. Although geographically separated, politically and economically different and with distinct patterns of economic development, these countries began to see themselves as a group largely because of foreign investor and media perceptions. Over the last 10 years, the BRICs have consolidated and even further expanded their strong position in the world economy.

Graph 1 shows that the BRICs have significantly increased their share of the world GDP (in Purchasing Power Parity / PPP), which is evidence of the group's dynamism. However, it is clear that the rise in the share of the BRICs of the global GDP is mostly related to the Chinese and Indian GDP growth. Moreover, as a 
general trend, the graph illustrates that while China and India experienced a substantial increase in their share of the world GDP in the 2000s, Brazil and Russia did not show a similar trend; rather, their shares of the world GDP have decreased.

Due to the evolution of the Chinese and Indian economies, the BRICs share of the world economy has increased from 16\% of the world GDP in 1990 to approximately $30 \%$ in 2010. This increase means that the BRICs' economic size expanded by $91 \%$ relative to the rest of the world in those two decades. In terms of combined GDP, the BRIC countries together are larger than the United States and the European Union.

Graph 1: Share of Global GDP in PPP

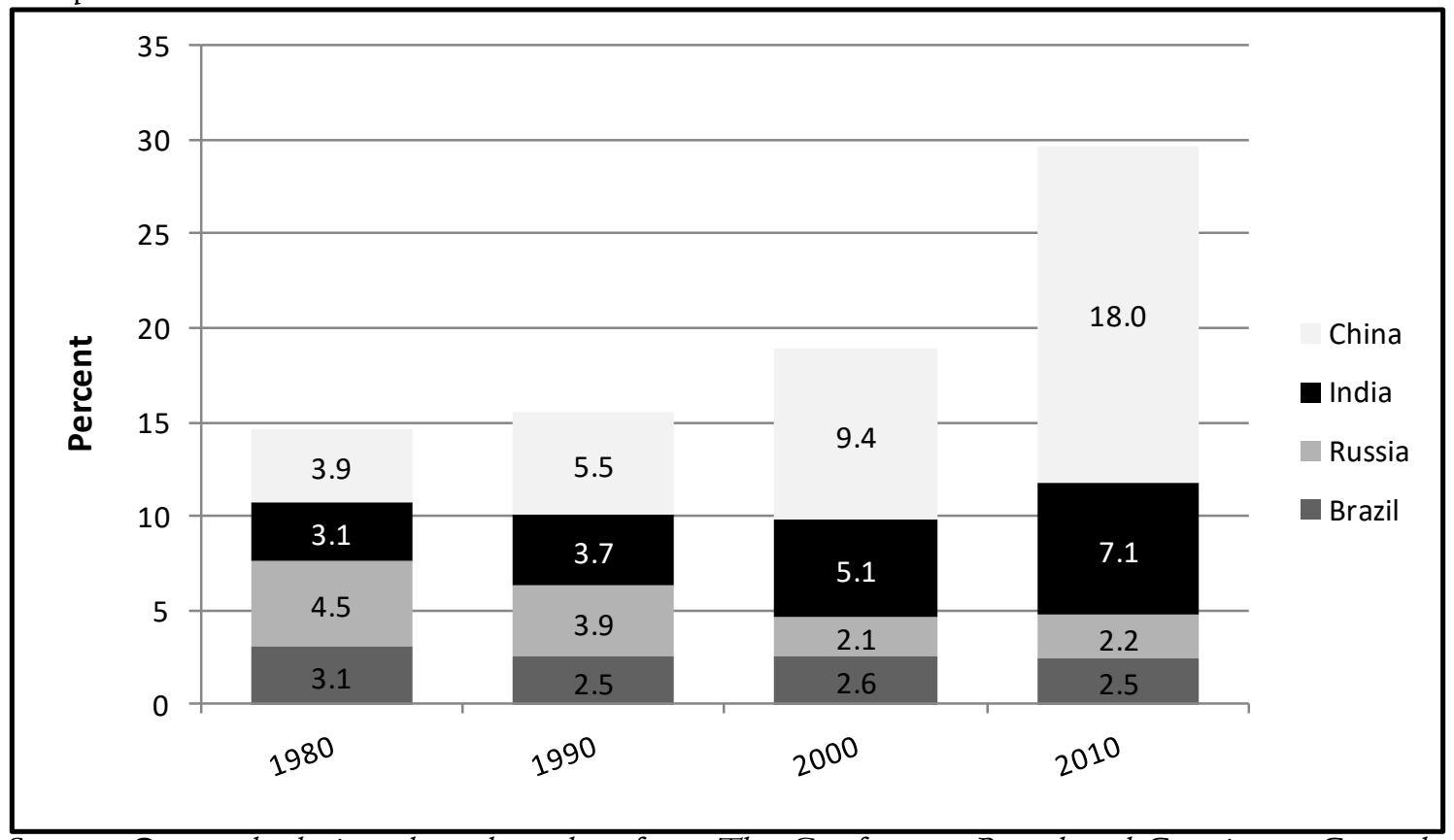

Source: Own calculations based on data from The Conference Board and Groningen Growth and Development Centre (Timmer et al., 2015). Note: Data for 1980 and 1990 include Soviet Union countries. Data for Russia are available from 1995 onward.

The structural changes observed in the BRIC countries in terms of production were significant because their sectoral shares of the GDP have changed considerably over recent decades. In China and India, the most dynamic economies in the BRIC group, the declining share of the primary sector in their respective GDPs has been a common trend over the years. In both cases, from the 1990s onward, the increase in services' share was not followed by a representative loss in manufacturing, and this framework is compatible with the developmental premise that industrialization is a central condition for economic development. The expansion of services took place with a decrease in the primary sector instead. In China, manufacturing represented the largest portion among all the BRIC countries (approximately $32 \%$ in the last decade), while in India this sector exhibited low 
but stable participation (approximately 15\%). Conversely, in Brazil and Russia, the share of the primary sector of the $\mathrm{GDP}^{5}$ remained relatively stable, while the expansion of services in the productive structure occurred to the detriment of manufacturing.

Regarding services, all the countries showed a very significant increase, revealing that this sector constituted the largest share of the GDP. However, in China and India, the increase in the share of services was not followed by a decrease in manufacturing, while Brazil and Russia have been losing the capacity to boost their economies through manufacturing, whose share of GDP declined, because their growth process was based on the expansion of the primary and service sectors.

Graph 2. Sectoral Shares of GDP

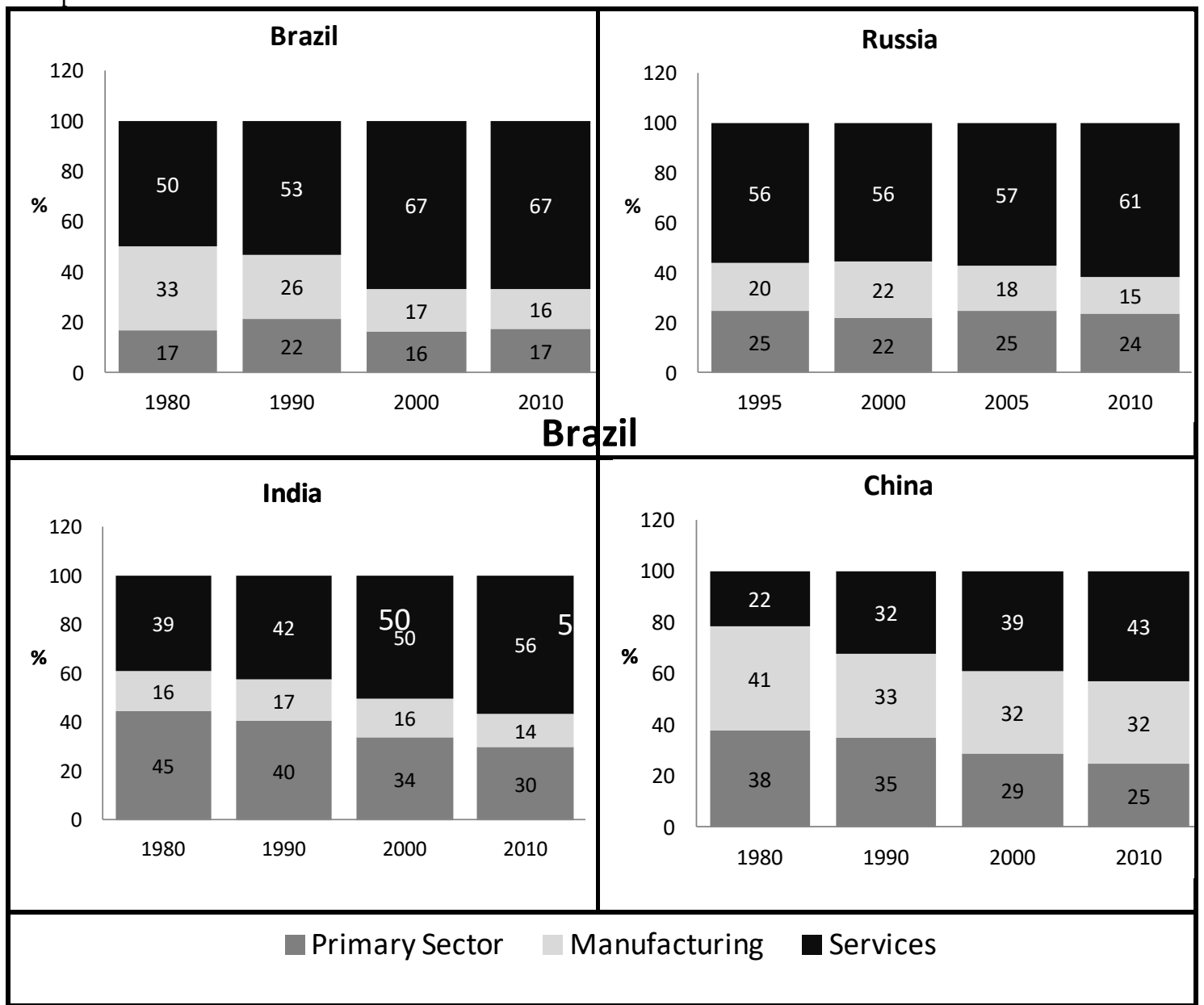

Source: Own calculations based on data from The Conference Board and Groningen Growth and Development Centre (Timmer et al., 2015). Note: The Primary Sector includes agriculture and mining; services include construction, utilities and other services (this aggregation does not follow the traditional definition for services). Percentage shares are at current prices.

${ }^{5}$ Data for Russia are available from 1995 onward. 
The link between industrial structure and global trade is another important aspect of the differences and similarities among the growth processes of the BRIC countries. In this way, exports have significantly contributed to the economic growth and structural transformation of the BRICs. Although during the first half of the 1980s, the BRIC countries accounted for less than $4.5 \%$ of world exports, by the second half of the 2000s, their combined share reached an average of $12.5 \%$ per annum. The primary contribution to this increase in terms of value has come from China, although Russia and India also contribute. After the so-called lost decade for the Latin American countries during the 1980s, Brazil recovered its previous share of exports in the global trade.

Graph 3. The BRICs' Shares of World Exports (5-year averages), 1980-2010

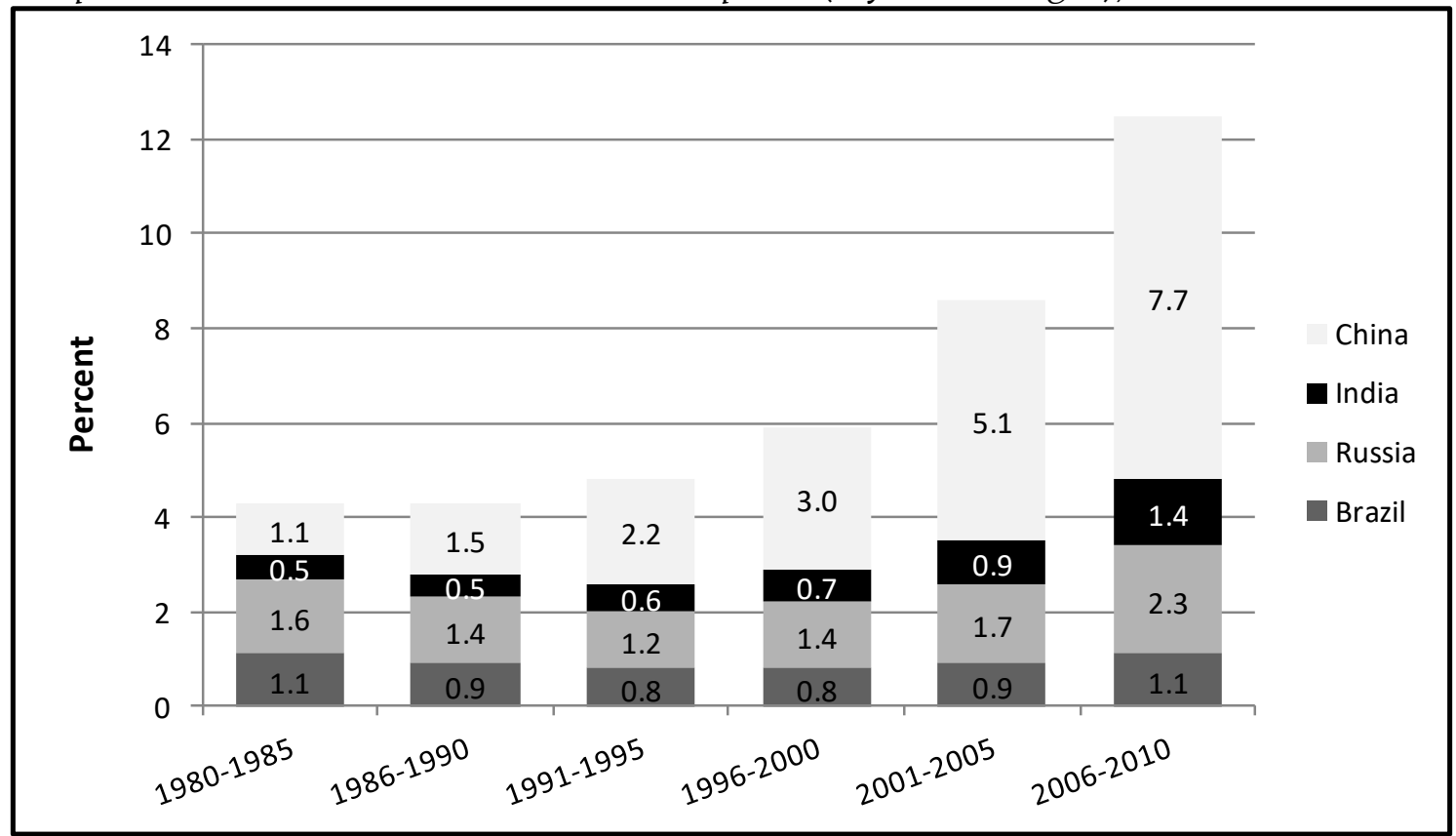

Source: UNIDO (2012). Note: Data for 1980 and 1990 include Soviet Union countries. Data for Russia are available from 1995 onward.

Trade from a sectoral perspective has also presented distinct characteristics in the BRICs. Graph 4 compares the BRICs' shares of manufactured and primary goods of total merchandise exports. The demand for primary products has been increasing over recent decades, specifically among the BRICS, mainly due to the strong growth of the Chinese and Indian manufacturing industries. During the 2000s, Brazilian exports were accompanied by a boom in commodity prices that increased the country's exports approximately 262 percent, almost twice the global average of 135 percent. This new economic reality resulted in an increase of exports' share of the country's gross domestic product (GDP) from 10\% in 2000, 
peaking at $16.4 \%$ in 2004 and dropping to $10.9 \%$ in $2010^{6}$ as a consequence of the global financial crisis. In spite of the crisis, Brazilian commodities played a key role in the economy's dynamism with the primary sector's share of exports peaking at 63\% in 2010 (Prates, 2006 and Rocha, 2011). A similar trend was exhibited by Russian exports, which are centrally based in the primary sector, specifically oil and gas. From 1995 to 2010, the share of primary exports in Russia increased almost $20 \%$, while the share of manufacturing exports decreased $50 \%$.

This dynamic also contributed to the currency appreciation and had an undesired negative effect on manufacturing export industries because it culminated in a loosening of competitiveness on the global trade market (a common phenomenon known as the Dutch Disease). Unlike the Russian and Brazilian trend, the share of manufacturing exports in India remained very high; however, it is decreasing. Moreover, the most remarkable data are shown by China, which enormously increased its share of manufacturing exports. China expanded the participation of manufacturing in its exports and has remained a very competitive country in the global market by managing an undervalued currency. If trade composition matters for growth, as many authors argue (Blecker and Razmi, 2010; Hausmann et al., 2007; Hausmann et al., 2014; Hirschman, 1958; Kaldor, 1989), this is another argument to explain the differences among the performances of the BRIC countries.

\footnotetext{
${ }^{6}$ Considering the series at constant prices (1980), exports' share of the GDP continued to increase even after 2004 and reached a peak in 2007, the year that preceded the global crisis.
} 
Graph 4. Sectoral Shares of Exports

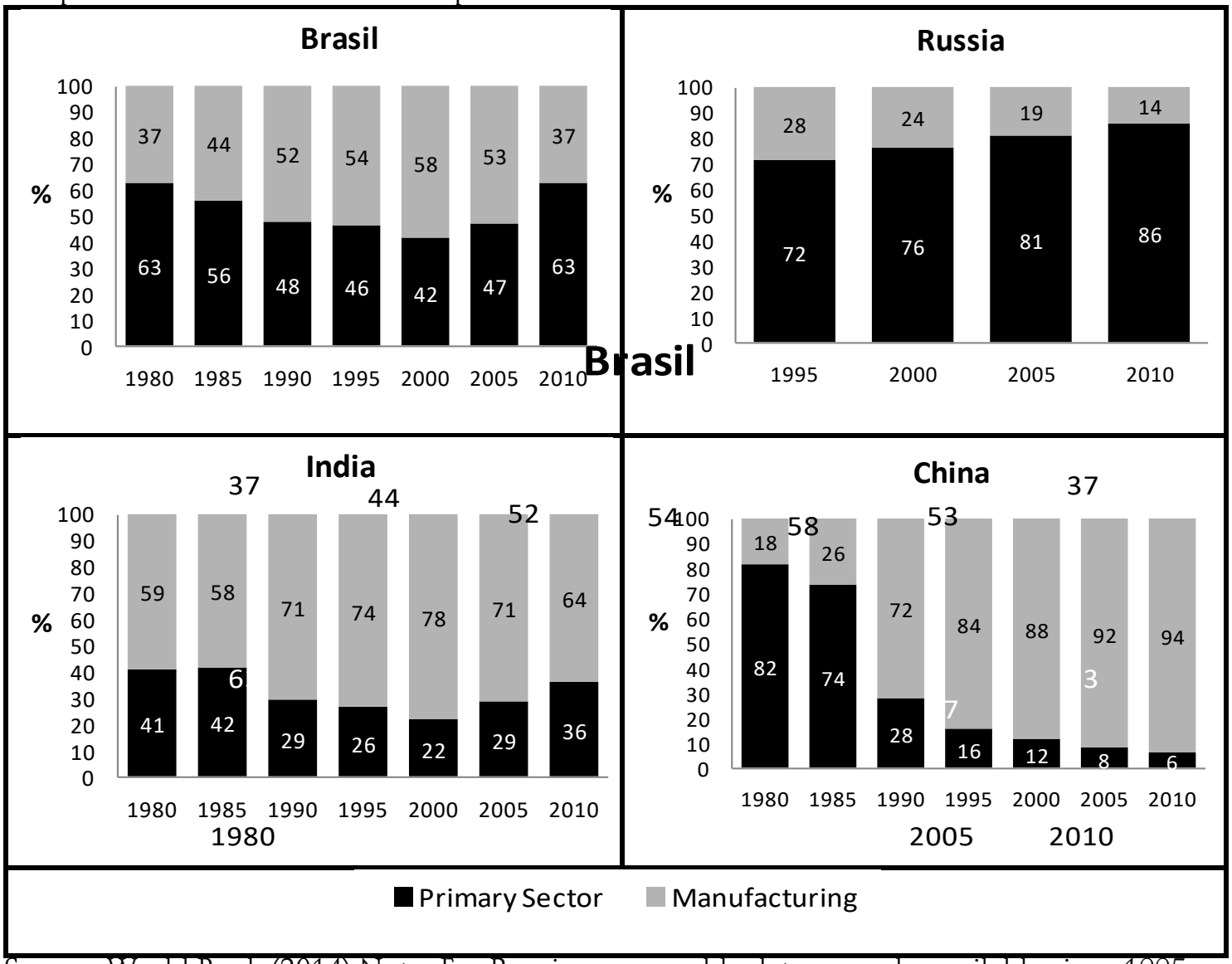

Source: World Bank (2014) Note: For Russia, comparable data are only available since 1995.

Data from the last ten years allow the inclusion of service exports in the analysis. Table 1 confirms that China is focused on manufactured exports, while modern services play an important but decreasing role in exports in India. These results show the relevance of discussion of the linkages of not only the primary and manufacturing sectors but also the service sector. The shares of primary exports in Brazil and Russia have increased and, as noted above, are the largest in these countries.

Table 1. Goods and services as share of total exports (period average, in \%)

\begin{tabular}{|c|c|c|c|c|c|c|c|c|}
\hline & \multicolumn{2}{|c|}{ Brazil } & \multicolumn{2}{|c|}{ China } & \multicolumn{2}{|c|}{ India } & \multicolumn{2}{|c|}{ Russia } \\
\hline & $2005-7$ & 2010-2 & 2005-7 & 2010-2 & $2005-7$ & 2010-2 & $2005-7$ & 2010-2 \\
\hline Primary goods & 42.1 & 54.7 & 6.5 & 5.7 & 20.6 & 23.7 & 66.2 & 69.0 \\
\hline $\begin{array}{l}\text { Manufactured } \\
\text { goods }\end{array}$ & 43.6 & 29.6 & 82.7 & 85.1 & 42.8 & 41.4 & 15.7 & 13.0 \\
\hline $\begin{array}{l}\text { Modern } \\
\text { services* }\end{array}$ & 6.0 & 8.4 & 2.8 & 3.2 & 26.2 & 23.3 & 3.1 & 3.6 \\
\hline $\begin{array}{l}\text { Traditional } \\
\text { services** }\end{array}$ & 6.0 & 5.2 & 7.8 & 5.9 & 9.8 & 10.0 & 7.7 & 7.0 \\
\hline $\begin{array}{l}\text { Miscellaneous } \\
\text { goods }\end{array}$ & 2.3 & 2.1 & 0.2 & 0.1 & 0.7 & 1.7 & 7.4 & 7.5 \\
\hline
\end{tabular}


Thus, it is clear that the BRICs' economic performances, exports and production structures vary significantly. Given that performance, both in terms of productive structure and global trade, many questions emerged about the capacity of the primary and service sectors to promote economic growth. In this way, this study sought to determine whether a primary or services-based growth process can actually support development in the long term by analyzing the linkage effects that the primary and service sectors can generate compared with those that sectors linked to manufactured products can create. The following section presents the theoretical and methodological background of the analysis.

\section{Theoretical foundations of the input-output model}

With the aim of analyzing the capacity of commodity production to boost the BRIC economies vis-à-vis manufactured goods, input-output analyses were used in this study. The decision to use the input-output methodology was based on the fact these models' ability to incorporate relationships among various industries of the BRIC countries. Using this methodology, it is possible to empirically investigate the economic role of a productive sector without restricting the analysis to its "direct effects" on the economy in terms of generating production, employment, value added, tax revenue, exports, and other effects but rather also measuring its "indirect effects", i.e., those that a sector can have on other sectors through channels established by input/output transactions between different economic sectors.

To calculate these indexes, input-output tables from 2000 to 2009 were used (at the level of 34 sectors), based on the World Input-Output Database (WIOD). Next, to reduce the number of sectors in which comparisons needed to be made among manufactured products, commodities and services, the tables were aggregated into 18 sectors of tradable goods distributed in these two groups based on the proximity of their production structures. The correspondence between the sectors of the initial matrix (34 sectors) and the resulting matrix (18 sectors) is shown in Appendix 1.

\subsection{Theoretical foundations}

Based on the pioneer analysis developed by Leontief (1951), the theoretical approach adopted in this study is based on the input-output model, in which the economy's total production $(X)$ is the result of the sum of the production intended for intermediate consumption by different sectors $(Z)$ and demand, which represents to what extent sector $j$ used goods produced by sector $i$ in its total 
production. That is, the input-output model shows the percentage of inputs sold to industry $\mathrm{j}$ by sector $\mathrm{i}$ in relation to the total production of sector $\mathrm{j}$.

$$
a_{i j}=\frac{Z_{i j}}{X_{j}}
$$

where $z_{i j}$ expresses the inter-sectoral sales of sector $\mathrm{i}$ to sector $\mathrm{j}$ and $x_{j}$ expresses the total production of sector j. Relationship (2) can thus be demonstrated:

$$
X=A X+Y
$$

where $A$ is the matrix of domestic technical coefficients and $Y$ is the vector of final demand. By solving this equation, the total output required to meet the final demand can be determined, i.e., (3):

$$
X=(I-A)^{-1} Y
$$

where $(I-A)^{-1}=L$ is the inverse of Leontief's matrix.

Using Leontief's model, various analyses can be carried out to assess the impact of demand variation on production, employment and value added, among other variables. Based on the ratio between the value of the variable assumed ${ }^{7}$ as $\mathrm{K}$ and the total production of the corresponding sector, the direct coefficient $(k)$ is calculated for each variable

$$
k_{j}=\frac{K_{j}}{X_{j}}
$$

Once $k$ is calculated, along with Leontief's inverse matrix (L), one can calculate, by sector, the amount directly and indirectly generated from variable $\mathrm{K}$ for each monetary unit produced for final demand. This is the generator notion, which relates production for final demand with a given variable of the economy. Thus, the generator of a variable $\mathrm{K}$ for each sector can be calculated by summing each column of matrix GK obtained in (5).

$$
G K=\sum_{i=1}^{n} \hat{k}_{i} \cdot L_{i j}
$$

\footnotetext{
${ }^{7} \mathrm{~K}$ may be any variable, such as employment, $\mathrm{P} \& \mathrm{D}$ expenses, value added or taxes.
} 
With the quotient between the generator and respective direct coefficient, one can obtain the multiplier of the variable assumed as $\mathrm{K}$, which associates the direct effect of a variable with its total (direct and indirect) effect on the economy, as represented in equation (6).

$$
M K_{j}=G K_{j} / k_{i}
$$

Multipliers for employment and production can thus be obtained ${ }^{8}$. Additionally, the input-output methodology allows for other indicators of economic importance to be calculated. Following the seminal works of Hirschman (1958) and Rasmussen (1956), one can define the interrelationships between the sectors and the power of each sector in the economy to establish linkages. The socalled Hirschman-Rasmussen backward linkage (BL) indexes determine how much a sector demands from other sectors, and the rates of forward linkages (FL) determine how much this sector is demanded by other sectors. To calculate the Hirschman-Rasmussen backward linkage index, one defines $l_{i j}$ as the elements of matrix $L, L^{*}$ as the average of all the elements of $\mathrm{L}$ and $L_{*_{j}}$ as the sum of a column of $L$. The equation may be represented as

$$
B L_{j}=\left(L_{*_{j}} / n\right) / L^{*}
$$

As for the Hirschman-Rasmussen forward linkage index, it is calculated from the matrix of coefficients in row (F) obtained from the intermediate consumption matrix (Z), as represented in (8).

$$
F=\hat{x}^{-1} \cdot Z
$$

As in Leontief's inverse matrix, the matrix of Ghost is deduced with $g_{i j}$

$$
G=(I-F)^{-1}
$$

Considering $G^{*}$ as the average of all the elements of $G$ and $G_{i *}$ as the sum of the elements in each row, the Hirschman-Rasmussen forward linkage index is obtained $^{9}$

\footnotetext{
${ }^{8}$ In this paper, type I multipliers were used, which only take into account multiplicative effects restricted to demand for intermediate inputs, that is, without making household demand endogenous to the model. If household demand were endogenized in the system, the induced effect would be taken into consideration and we would have the type II multiplier (Guilhoto, 2009).

${ }^{9}$ For more details, see Miller and Blair (2009).
} 


$$
F L_{i}=\left(G_{i^{*}} / n\right) / G^{*}
$$

Depending on the result of the indexes, sectors can be classified into four groups, namely, (i) independent from (or not very related to) other sectors, if both linkage indexes are less than 1; (ii) dependent on (or strongly related to) other sectors, if both linkage indexes are greater than 1 , denoting sectors that are seen as playing a key role in the economy; (iii) dependent on inter-sectoral supply, if only the backward linkage index is greater than 1; and (iv) dependent on inter-sectoral demand, if only the forward linkage index is greater than 1. However, as first observed by Cella (1984) and Clements (1990), these indexes do not take into account the production levels of each analyzed sector.

As an attempt to correct and refine the solutions presented by these authors, Guilhoto et al. (1994) introduced a first version of what would be referred to as pure linkage indexes, later known as the GHS methodology. In Guilhoto, Sonis and Hewings (2005), some decompositions of Leontief's inverse matrix are made that consist of integrating the main techniques used in analyses of input-output structures with the aim of decomposing and distinguishing the impact of a sector of the economy on its various components. The consolidated GHS methodology is based on a block matrix of technical coefficients (A)

$$
A=\left[\begin{array}{cc}
A_{j j} & A_{j r} \\
A_{r j} & A_{r r}
\end{array}\right]
$$

where $A$ is composed of square and rectangular matrices. $A_{j j}$ and $A_{\text {rrrepresent }}$ square matrices of direct technical coefficients of sector $j$ and of the rest of the economy (the economy as an entire less sector $\mathrm{j}$ ), respectively, while $A_{\mathrm{jr}}$ and $A_{\mathrm{rj}}$ represent rectangular matrices of direct inputs purchased by sector $j$ from the rest of the economy and direct inputs purchased by the rest of the economy from sector $\mathrm{j}$.

Based on this matrix A, expressed in (11), a triple multiplicative decomposition of Leontief's inverse matrix can be made as follows

$$
L=(I-A)^{-1}=\left[\begin{array}{cc}
L_{j j} & L_{j r} \\
L_{r j} & L_{r r}
\end{array}\right]=\left[\begin{array}{cc}
\Delta_{j j} & 0 \\
0 & \Delta_{r r}
\end{array}\right]\left[\begin{array}{cc}
\Delta_{j} & 0 \\
0 & \Delta_{r}
\end{array}\right]\left[\begin{array}{cc}
I & A_{j r} \Delta_{r} \\
A_{r j} \Delta_{j} & I
\end{array}\right]
$$

where

$$
\Delta_{j}=\left(I-A_{j j}\right)^{-1}
$$




$$
\begin{aligned}
& \Delta_{r}=\left(I-A_{r r}\right)^{-1} \\
& \Delta_{j j}=\left(I-\Delta_{j} A_{j r} \Delta_{r} A_{r j}\right)^{-1} \\
& \Delta_{r r}=\left(I-\Delta_{r} A_{r j} \Delta_{j} A_{j r}\right)^{-1}
\end{aligned}
$$

From Leontief's model expressed in (3) and equation (12), the following results

$$
\left(\begin{array}{c}
X_{j} \\
X_{r}
\end{array}\right)=\left(\begin{array}{cc}
\Delta_{j j} & 0 \\
0 & \Delta_{r r}
\end{array}\right)\left(\begin{array}{c}
\Delta_{j} Y_{j}+\Delta_{j} A_{j r} \Delta_{r} Y_{r} \\
\Delta_{r} A_{r j} \Delta_{j} Y_{j}+\Delta_{r} Y_{r}
\end{array}\right)
$$

Through this process, pure backward linkage (PBL) and forward linkage (PFL) indexes can be deduced in their new definition, namely

$$
\begin{aligned}
& P B L=\Delta_{r} A_{r j} \Delta_{j} Y_{j} \\
& P F L=\Delta_{j} A_{j r} \Delta_{r} Y_{r}
\end{aligned}
$$

In equation (18), the index shows the impact of the value of the total output of sector $\mathrm{j}$ on the rest of the economy, net of demand for inputs that sector $\mathrm{j}$ produces for itself and returns of the rest of the economy for sector $j$ and vice versa. In turn, the PFL in equation (19) indicates the impact of the value of the total production of the rest of the economy on sector $j$. For calculating the pure index for all linkages (PTL) in each sector in the economy, it is necessary to add the PBL and the PFL, expressed in current values:

$$
P T L=P B L+P F L
$$

However, because these indexes do not take into account the size of the sectors, which is important for identifying key sectors of the economy, a "normalization" procedure should be applied to their indexes based on the approach of normalized pure linkage indexes. For this purpose, the pure indexes of each sector are divided by the average of pure indexes for the economy as a whole. Thus, the normalized pure backward linkage index (PBLN), the normalized pure forward linkage index (PFLN) and the total index (PTLN) can be represented by

$$
\begin{aligned}
& P B L N_{i}=P B L_{i} /\left(\sum_{i=1}^{n} P B L_{i} / n\right) \\
& \operatorname{PFLN}_{i}=\operatorname{PFL}_{i} /\left(\sum_{i=1}^{n} \operatorname{PFL}_{i} / n\right)
\end{aligned}
$$




$$
\operatorname{PTLN}_{i}=P T L_{i} /\left(\sum_{i=1}^{n} P T L_{i} / n\right)
$$

\section{Results}

This section presents the results obtained using the proposed methodology based on the input-output analysis in the following order: output multipliers, Rasmussen-Hirschman backward and forward linkage indexes (BL and FL), and pure normalized backward and forward linkage indexes (PBLN and PFLN).

The output multiplier indicates how much is produced for each monetary unit spent on final consumption. In other words, these multipliers incorporate direct and indirect effects to measure the impacts of a demand shock on total output. For the purposes of this analysis, type I multipliers are used, which only consider linked effects restricted to demand for intermediate inputs, that is, without making household demand endogenous to the model.

The multipliers differ significantly among countries in terms of both absolute and relative magnitudes. The Chinese multipliers are higher for every sector; the only exception is the Brazilian petroleum industry. This fact means that Chinese industry is more interrelated than other BRICs' industries and, consequently, that an increase in final demand in China has a greater impact on the domestic economy than an increase in final demand in all the other analyzed economies. Furthermore, Table 2 shows that all the manufacturing sectors in China present multipliers higher than 2.0, and outside manufacturing, only construction and business services present such high multipliers. Owing to these high multipliers, Chinese manufacturing is a dynamic sector able to boost economic growth by increasing total demand more than twice as much as any increase in final demand.

Table 2 also shows the relative importance of a given sector for each country. One of the most important sectors for all the analyzed countries is transport equipment. This sector has high multipliers in all the BRICs, which indicates that it is characterized by a high potential to stimulate demand in other sectors. An increase in transport equipment final demand stimulates demand for metal, electrical and chemical products directly but also for mineral commodities and petroleum indirectly because these products are used in the production of parts and components. It is important to consider, however, that the Chinese multiplier for transport equipment is higher than those in the other BRICs. 
Primary commodities (agricultural and mineral) present the lowest multipliers comparing the tradable goods in all four economies. This finding means that although these sectors may contribute to economic growth, they are not able to boost demand in other sectors, and thus an increase in final demand for commodities does not significantly increase the total output. It is important to emphasize that in all the BRICs, the multipliers in manufacturing are larger than in the primary and service (both modern and traditional) sectors, with the exception of utilities and construction ${ }^{10}$.

Table 2. Output Multipliers: 2000-2011

\begin{tabular}{|c|c|c|c|c|c|c|c|c|}
\hline & \multicolumn{2}{|c|}{ Brazil } & \multicolumn{2}{|c|}{ China } & \multicolumn{2}{|c|}{ India } & \multicolumn{2}{|c|}{ Russia } \\
\hline & Mult & Rank & Mult & Rank & Mult & Rank & Mult & Rank \\
\hline Agricultural commodities & 1.62 & 13 & 1.84 & 18 & 1.34 & 15 & 1.72 & 13 \\
\hline Mineral commodities & 1.79 & 10 & 2.03 & 14 & 1.36 & 14 & 1.63 & 15 \\
\hline Food and beverage & 2.24 & 1 & 2.45 & 9 & 2.22 & 1 & 2.12 & 1 \\
\hline Textiles and footwear & 1.94 & 6 & 2.80 & 2 & 2.15 & 3 & 1.80 & 11 \\
\hline Miscellaneous & 1.86 & 9 & 2.57 & 6 & 1.81 & 10 & 1.99 & 7 \\
\hline Petroleum and fuels & 2.17 & 2 & 2.14 & 12 & 1.64 & 12 & 1.96 & 8 \\
\hline Chemical products & 2.00 & 4 & 2.63 & 5 & 2.15 & 4 & 2.05 & 3 \\
\hline Non-Metallic Minerals & 1.89 & 7 & 2.53 & 8 & 1.94 & 8 & 2.02 & 5 \\
\hline Metal products (incl. Machinery) & 1.96 & 5 & 2.67 & 4 & 2.13 & 5 & 2.08 & 2 \\
\hline Electric and optical & 1.88 & 8 & 2.56 & 7 & 2.08 & 6 & 2.04 & 4 \\
\hline Transport equipment & 2.13 & 3 & 2.84 & 1 & 2.21 & 2 & 1.92 & 9 \\
\hline Utilities & 1.67 & 12 & 2.35 & 10 & 2.00 & 7 & 2.01 & 6 \\
\hline Construction & 1.72 & 11 & 2.72 & 3 & 1.92 & 9 & 1.87 & 10 \\
\hline Sales & 1.41 & 19 & 1.85 & 17 & 1.20 & 18 & 1.52 & 18 \\
\hline Traditional services & 1.52 & 15 & 1.94 & 16 & 1.69 & 11 & 1.65 & 14 \\
\hline Financial services & 1.50 & 17 & 1.64 & 19 & 1.33 & 16 & 1.49 & 19 \\
\hline Business services & 1.56 & 14 & 2.18 & 11 & 1.43 & 13 & 1.61 & 17 \\
\hline Public administration & 1.49 & 18 & 1.98 & 15 & 1.00 & 19 & 1.76 & 12 \\
\hline Health and education & 1.51 & 16 & 2.09 & 13 & 1.30 & 17 & 1.61 & 16 \\
\hline
\end{tabular}

Source: Elaborated by the authors based on World Input-Output Database (Timmer et al., 2015b).

The analysis of industrial multipliers can be complemented by the Hirschman-Rasmussen forward and backward linkage indexes. As highlighted by Guilhoto (2009), the Hirschman-Rasmussen linkage index analyzes the relationship between each sector and the remaining sectors of the economy. The backward linkage index is used to assess the degree of linkage in sector $j$ in relation to the degree of linkage in the economy as a whole. Based on the results, one can infer to what extent the output of a particular sector stimulates the production of its inputs.

${ }^{10}$ Following the previous definition, finance and business are considered modern services. 
The forward linkage index, in turn, makes it possible to analyze the importance of that sector as an input supplier. Through these indicators, the behavior of the economy's internal structure can be studied, and one can identify its key sectors that depend on inter-industrial supply or inter-industrial demand, or the sectors that are relatively independent from the others.

The most important sectors in terms of stimulating the production of inputs vary among countries. For Brazil, they are food/beverage, petroleum and transport equipment; for China, transport equipment, textiles/footwear and construction; for India, transport equipment, food/beverage, textiles/footwear and chemical products; and for Russia, food/beverage, metal products and electric/optical. These sectors are those with greater potential to boost economic growth given an increase in final demand. The food/beverage industry plays an important role in precipitating economic growth for Brazil, India and Russia because these countries have relevant agricultural production. However, as shown in Table 3, transport and metal products present high backward linkages for all four countries, which indicates that these sectors are characterized by a high potential to precipitate economic growth because they demand more inputs than other sectors in the economy. Again, the largest backward linkage indexes were found in manufacturing sectors, while the lowest among tradable goods were found in primary commodities. Traditional and modern services also exhibit relatively low backward linkages and hence have a limited capacity to boost the production of other sectors. This finding reinforces the argument that the service sectors, even those with greater technological content, cannot be considered a lever for other sectors' output growth.

Regarding forward linkage indexes, we see that utilities, petroleum, chemical products and mineral commodities are the most relevant sectors. There is a combination of the manufacturing and primary sectors in this situation because products in the primary sector are, in general, inputs for other sectors in the production chain. The petroleum sector stands out as having the greatest capacity to supply inputs to the remaining sectors for all the analyzed economies. Although it falls in the commodity category, petroleum is characterized by a high production rate for each monetary unit spent on final consumption. This is so because this sector is a supplier of inputs for manufacturing the main industrialized products of the chemical products and synthetic materials sector and of the apparel sector instead of being exported as a raw material. The forward linkages for modern services strengthen their role as suppliers for other sectors. 
By analyzing together the backward and forward linkages, it is possible to identify the key sectors in the BRICs, which are those sectors with both indicators higher than one. The only sectors that can be considered key using this criterion are metal and chemical products. They showed a high potential to boost other sectors of the economy in addition to being major input suppliers. Notably, there is no manufacturing sector in the group that is relatively independent from the others (with backward and forward linkages lower than one), indicating that there is a significant degree of dependence among several industrial sectors of the economy. This result indicates that manufacturing sectors are usually more interrelated with other sectors than primary goods and services. Finally, among sectors that are strongly dependent on inter-industrial supply (with backward linkages higher than one but forward linkages lower than one), special mention should be made of those of food/beverage, textiles/footwear and transport equipment. These results help show the importance of these sectors and their capacity to pull the other ones up. Forward linkages are larger than backward linkages for services, and traditional services exhibit lower forward linkages than modern services (with the exception of business services in India and financial services in Russia, remarkably). These findings show that their production depend on other sectors' growth, reinforcing the argument that they - mainly modern services - are complementary to the output of other sectors.

Table 3. Hirschman-Rasmussen linkage indexes: 2000-2011

\begin{tabular}{lcccccccc}
\hline & \multicolumn{3}{c}{ Backward linkages (BL) } & \multicolumn{5}{c}{ Forward linkages (FL) } \\
& BRA & CHN & IND & RUS & BRA & CHN & IND & RUS \\
\hline Agricultural commodities & 0.91 & 0.80 & 0.78 & 0.94 & 1.09 & 0.98 & 0.86 & 0.93 \\
Mineral commodities & 1.00 & 0.88 & 0.79 & 0.89 & 1.38 & 1.53 & 1.48 & 0.92 \\
Food and beverage & 1.26 & 1.06 & 1.28 & 1.15 & 0.83 & 0.86 & 0.72 & 0.75 \\
Textiles and footwear & 1.09 & 1.21 & 1.24 & 0.98 & 0.86 & 0.87 & 0.78 & 0.86 \\
Miscellaneous & 1.04 & 1.11 & 1.04 & 1.09 & 1.07 & 1.20 & 0.93 & 1.11 \\
Petroleum and fuels & 1.22 & 0.93 & 0.95 & 1.07 & 1.21 & 1.38 & 1.31 & 1.36 \\
Chemical products & 1.12 & 1.14 & 1.24 & 1.12 & 1.21 & 1.29 & 1.16 & 1.18 \\
Non-Metallic Minerals & 1.06 & 1.10 & 1.12 & 1.10 & 1.25 & 1.02 & 1.25 & 1.26 \\
Metal products (incl. & 1.10 & 1.16 & 1.23 & 1.13 & 1.05 & 1.14 & 1.18 & 1.12 \\
Machinery) & & & & & & & & \\
Electric and optical & 1.06 & 1.11 & 1.20 & 1.11 & 0.90 & 0.81 & 0.86 & 1.13 \\
Transport equipment & 1.19 & 1.23 & 1.28 & 1.05 & 0.78 & 0.90 & 0.88 & 0.95 \\
Utilities & 0.94 & 1.02 & 1.15 & 1.09 & 1.28 & 1.48 & 1.50 & 1.43 \\
Construction & 0.96 & 1.18 & 1.11 & 1.02 & 0.68 & 0.44 & 0.72 & 0.63 \\
Sales & 0.79 & 0.81 & 0.69 & 0.83 & 1.06 & 0.95 & 1.10 & 0.99 \\
Traditional services & 0.85 & 0.84 & 0.97 & 0.90 & 0.90 & 0.92 & 0.93 & 0.96 \\
Financial services & 0.84 & 0.71 & 0.77 & 0.81 & 1.05 & 1.19 & 1.32 & 0.81 \\
Business services & 0.87 & 0.95 & 0.83 & 0.88 & 1.09 & 1.02 & 0.82 & 1.15 \\
Public administration & 0.84 & 0.86 & 0.58 & 0.96 & 0.58 & 0.41 & 0.56 & 0.81 \\
Health and education & 0.85 & 0.91 & 0.75 & 0.88 & 0.74 & 0.61 & 0.66 & 0.65 \\
\hline Source: Elaborated by the authors based on World Input-Output Database (Timmer et al., 2015b).
\end{tabular}


However, it should be stressed that the Hirschman-Rasmussen index does not consider the size of sectors in the economy, an aspect that helps identify key sectors. For this reason, Table 4 shows these indexes normalized by the sector size. The first assesses the importance of the sectors as exhibiting demand for the other sectors' inputs, and the second the sector's capacity to supply inputs to the domestic industry. The difference between normalized and non-normalized pure linkage indices is especially significant for large sectors. In these sectors, the size is more relevant to explain the results than the capacity to increase, by each unit produced, the demand and supply of other sectors.

In this way, food/beverage, traditional services and construction occupy the three first positions of the backward indexes. The food/beverage sector stands out as having the highest index because of the importance of demand for its inputs from other industrial complexes but also due to its size compared with the other sectors. Additionally, certain sectors in each country should be highlighted: transport equipment in Brazil, electric/optical in China, textiles/footwear in India and metal products in Russia. All are classified as manufacturing. These sectors have a high pure impact, demanded inputs from the other economic sectors over the period 2000-2011, and present relatively more importance than others in these economies.

Considering the forward linkages, as would be expected, the index was higher for products with a lower degree of processing employed in the production of other goods. The transport equipment and electric/optical sectors, whose degree of processing is higher and whose chain is closer to final goods, present very low pure normalized forward linkages. Agricultural commodities (except in Russia), some services, and metal and chemical products present high pure normalized forward linkages because they are important suppliers for the economy as a whole. Moreover, it must be noted that mineral commodities are important as suppliers for domestic industry in China and Russia. Although Brazil produces these minerals, this production is mainly intended for exports. Consequently, mineral commodities are not processed domestically and thus are not drivers of the development of the metal-machinery industry. 
Table 4. Pure normalized backward and forward linkage indexes: 2000-2011

\begin{tabular}{lcccccccc}
\hline & \multicolumn{3}{c}{ Backward (PBLN) } & \multicolumn{4}{c}{ Forward (PFLN) } \\
& BRA & CHN & IND & RUS & BRA & CHN & IND & RUS \\
\hline Agricultural commodities & 0.57 & 0.64 & 0.92 & 0.77 & 1.56 & 1.46 & 1.97 & 0.94 \\
Mineral commodities & 0.31 & 0.07 & 0.09 & 1.55 & 0.93 & 1.06 & 0.64 & 1.05 \\
Food and beverage & 2.68 & 1.18 & 2.57 & 1.86 & 0.66 & 0.72 & 0.26 & 0.28 \\
Textiles and footwear & 0.52 & 1.18 & 1.59 & 0.14 & 0.16 & 0.48 & 0.20 & 0.07 \\
Miscellaneous & 0.53 & 0.28 & 0.78 & 0.43 & 0.75 & 0.99 & 0.62 & 0.63 \\
Petroleum and fuels & 0.67 & 0.05 & 0.33 & 0.48 & 1.00 & 0.69 & 1.65 & 1.64 \\
Chemical products & 0.74 & 0.47 & 0.84 & 0.43 & 1.56 & 2.17 & 1.24 & 0.75 \\
Non-Metallic Minerals & 0.05 & 0.13 & 0.09 & 0.07 & 0.44 & 1.06 & 0.67 & 0.57 \\
Metal products (incl. & 0.94 & 1.13 & 1.17 & 1.29 & 1.08 & 2.89 & 2.03 & 1.59 \\
Machinery) & & & & & & & & \\
Electric and optical & 0.57 & 2.17 & 0.84 & 0.27 & 0.32 & 0.92 & 0.30 & 0.39 \\
Transport equipment & 1.37 & 0.94 & 1.14 & 0.53 & 0.21 & 0.47 & 0.41 & 0.40 \\
Utilities & 0.23 & 0.09 & 0.18 & 0.29 & 1.08 & 1.05 & 1.22 & 2.09 \\
Construction & 1.62 & 5.65 & 4.06 & 2.70 & 0.36 & 0.11 & 0.70 & 0.26 \\
Sales & 0.77 & 0.65 & 0.38 & 2.05 & 2.28 & 1.14 & 2.61 & 3.31 \\
Traditional services & 2.10 & 1.26 & 2.78 & 2.12 & 2.40 & 1.98 & 2.42 & 2.45 \\
Financial services & 0.48 & 0.10 & 0.12 & 0.48 & 1.45 & 0.69 & 1.47 & 0.36 \\
Business services & 0.66 & 0.43 & 0.36 & 0.40 & 1.69 & 0.72 & 0.33 & 1.29 \\
Public administration & 2.05 & 0.96 & 0.00 & 1.49 & 0.11 & 0.01 & 0.00 & 0.67 \\
Health and education & 2.13 & 1.59 & 0.75 & 1.66 & 0.95 & 0.38 & 0.28 & 0.26 \\
\hline Source: Elaborated by the authors based on World Input-Output Database (Timmer et al., 2015b).
\end{tabular}

\section{Concluding remarks}

The complex relationship between the production structure and economic growth has been the subject of heated debate among economists. In the 2000s, the BRICs experienced a period of growth that, along with the potential markets of those large countries, affected many markets and policy makers. The growth path of Brazil and Russia were based on the production and export of primary goods, while in China and India, the pattern of industrial development remained grounded in manufacturing exports and services, respectively. These distinct economic growth paths resulted in a vast range of interpretations about sectors that act as the relevant engines of growth. On the one hand, some economists support the idea that expansion based on the production and export of commodities or services did not have a negative effect. According to them, in addition to being capable of generating income in export sectors, the primary and service sectors also have indirect effects on other productive chains and capacity to generate additional income to consumption that feeds back into domestic production. Alternatively, the main argument of those who do not support economic growth based on primary product exports is that manufacturing is the main engine of economic development. According to this view, development is essentially a process of 
structural change. Broadly speaking, sustained economic growth is associated with the capacity to diversify the structure of domestic production, i.e., generate new activities to expand possibilities of production, linkages and higher-value-added goods by providing incentives for manufacturing.

With the aim of analyzing the performances of the BRIC countries in recent decades, highlighting the differences among their production structures and trade compositions, this study assessed the potential of each sector to promote economic growth. Sectoral output multipliers, Rasmussen-Hirschman backward and forward linkage indexes, and pure normalized backward and forward linkage indexes were calculated to assess each sector's potential to promote other sectors. If the stimulus generated by a sector has a large impact on the others, we can conclude that a certain orientation has a higher potential to stimulate the economy as a whole. The aim of this approach is to evaluate whether a primary-, service- or manufacturingoriented growth path presents better results for growth.

The main findings were that manufacturing is the sector where the multipliers are the highest, while they are the lowest in agriculture and mineral commodities, which corroborates the hypothesis that having a dynamic manufacturing sector is essential to promote economic growth. The results also showed that Chinese multipliers are higher for all the analyzed sectors, indicating a higher degree of integration in China than in the other BRICs. Furthermore, the analysis of the backward linkages shows that in all the BRIC countries, chemical, transport, metal and food and beverage products have a significant potential (their estimated indexes are larger than one) to precipitate economic growth, and the analysis of the forward linkages shows that the non-metallic minerals, mineral commodities, utilities, chemical and petroleum sectors have the greatest capacity to supply inputs to the remaining sectors. Therefore, a strategy that seeks to boost economic growth must take into account the advantages of a production structure oriented toward expanding manufacturing and based on the utilization of commodities to promote other sectors in the economy. According to the adopted criteria, a primary goods-oriented strategy is unable to promote economic growth because it has a lower impact on aggregate output than a strategy focused on manufacturing production. The service sectors do not show relevant potential to precipitate economic growth because the indexes calculated for those sectors are smaller than for manufacturing, utilities and, in some cases, primary goods. Because forward linkages are larger than backward linkages for services, and modern services present slightly larger forward linkages than those observed for traditional services, the hypothesis that the output of services depends on the production in 
other sectors is reinforced, and the relation between modern services and other sectors constitutes a relevant issue for future research.

\section{References}

Blecker, R. A., \& Razmi, A. (2010). Export-led Growth, Real Exchange Rates and the Fallacy of Composition. In M. Setterfield (Ed.), Handbook of Alternative Theories of Economic Growth (pp. 379-396). Cheltenham: Edward Elgar Publishing. https://doi.org/10.4337/9781849805582.00030

Bresser-Pereira, L. C. (2008). The Dutch disease and its neutralization: a Ricardian approach. Revista de Economia Política, 28(1), 47-71. https://doi.org/10.1590/s0101-31572008000100003

Brunnschweiler, C. (2008). Cursing the Blessings? Natural Resource Abundance, Institutions, and Economic Growth. World Development, 363), 399-419. https://doi.org/10.1016/J.WORLDDEV.2007.03.004

Bulte, E. H., Damania, R., \& Deacon, R. T. (2005). Resource intensity, institutions, and development. World Development, 33(7), 1029-1044. https://doi.org/https://doi.org/10.1016/j.worlddev.2005.04.004

Cella, G. (1984). The input-output measurement of interindustry linkages. Oxford Bulletin of Economics and Statistics, 40(1), 73-84. https://doi.org/10.1111/j.1468-0084.1984.mp46001005.x

Chayanov, A. (1966). The theory of peasant economy. (B. K. Thorner \& R. Smith, Eds.). Homewood, IL: Richard D. Irwin, Inc.

Chenery, H., Robinson, S., \& Syrquin, M. (1986). Industrialization and Growth. New York: Oxford University Press.

Clements, B. J. (1990). On the decomposition and normalization of interindustry linkages. Economics Letters, 33(4), 337-340. https://doi.org/10.1016/01651765(90)90084-E

Corden, W. M., \& Neary, J. P. (1982). Booming Sector and De-Industrialisation in a Small Open Economy. The Economic Journal, 92(368), 825-848. https://doi.org/10.2307/2232670

Cornwall, J. (1977). Modern Capitalism, It's Growth and Transformation. New York: St. Martin's Press. 
Daniele, V. (2011). Natural Resources and the 'Quality' of Economic Development. Journal of Development Studies, 47(4), 545-573. https://doi.org/10.1080/00220388.2010.506915

Dasgupta, S., \& Singh, A. (2005). Will Services be the New Engine of Indian Economic Growth? Development and Change, 366), 1035-1057. https://doi.org/10.1111/j.0012-155X.2005.00449.x

Dasgupta, S., \& Singh, A. (2007). Manufacturing, Services and Premature Deindustrialization in Developing Countries: A Kaldorian Analysis. In Advancing Development (pp. 435-454). London: Palgrave Macmillan UK. https://doi.org/10.1057/9780230801462_23

Davis, G. A. (1995). Learning to love the Dutch disease: Evidence from the mineral economies. World Development, 23(10), 1765-1779. https://doi.org/10.1016/0305-750X(95)00071-J

Dixon, R., \& Thirlwall, A. P. (1975). A model of regional growth-rate differences on Kaldorian lines. Oxford Economic Papers, 27(2), 201-214. https://doi.org/10.1093/oxfordjournals.oep.a041312

Eichengreen, B., \& Gupta, P. (2012). The real exchange rate and export growth: are services different? MPRA Paper. (No. 43358). University of California, Berkeley. Retrieved from http://mpra.ub.uni-muenchen.de/43358/. Accessed on February 15 $5^{\text {th }}, 2019$.

Evangelista, R., Lucchese, M., \& Meliciani, V. (2014). Manufacturing exports and the impact on business services. In Workshop Explaining Economic Change (pp. 1-31). Roma: Sapienza Università di Roma. Available at http://citeseerx.ist.psu.edu/viewdoc/summary?doi=10.1.1.725.3639.

Accessed on February 15 $5^{\text {th }}, 2019$.

Fagerberg, J., \& Verspagen, B. (1999). Modern Capitalism in the 1970s and 1980s. In M. Setterfield (Ed.), Growth, Employment and Inflation. Houndmills, Basingstoke: MacMillan.

Furtado, C. (2000). Elementos de uma teoria do subdesenvolvimento. In R. Bielschowsky (Ed.), Cinquenta anos de pensamento na CEPAL (vol.1, pp. 240-262). Rio de Janeiro: Record. https://doi.org/1961(Original work published in 1961)

Ghani, E., Goswami, A. G., \& Kharas, H. (2011, December). Can services be the next growth escalator? Vox, CEPR Policy Portal. Retrieved from 
http://www.voxeu.org/article/can-services-be-next-growth-escalator. Accessed on February 15 ${ }^{\text {th }}, 2019$.

Guilhoto, J. (2009). Análise de Insumo-Produto: teoria, fundamentos e aplicações. São Paulo: Department of Economics, FEA-USP.

Guilhoto, J., Sonis, M., \& Hewings, G. J. D. (2005). Linkages and Multipliers in a Multiregional Framework: Integration of Alternative Approaches. SSRN Electronic Journal, (8). https://doi.org/10.2139/ssrn.2419585

Guilhoto, J., Sonis, M., Hewings, G., \& Martins, E. (1994). Índices de ligações e setores-chave na economia brasileira: 1959/80. Pesquisa e Planejamento Econômico, 24(2), 287-314.

Hausmann, R., Hidalgo, C. A., Bustos, S., Coscia, M., Simoes, A., \& Yildirim, M. A. (2014). The Atlas of Economic Complexity. Cambridge, MA: The MIT Press. https://doi.org/10.7551/mitpress/9647.001.0001

Hausmann, R., Hwang, J., \& Rodrik, D. (2007). What you export matters. Journal of Economic Growth, 12(1), 1-25. https://doi.org/10.1007/s10887-0069009-4

Hirschman, A. (1958). The Strategy of Economic Development. New Haven, TC: Yale University Press.

Kaldor, N. (1981). The role of increasing returns, technical progress and cumulative causation in the theory of international trade and economic growth. Economie Appliquee, 34(6), 593-617.

Kaldor, N. (1989). Causes of the slow rate of economic growth in the United Kingdom. In F. Targetti \& A. Thirlwall (Eds.), The Essential Kaldor. New York: Holmes \& Meier Publishers. (Original work published in 1966)

Leontief, W. (1951). The Structure of the American Economy (2nd ed.). New York: Oxford University Press.

Lewis, A. W. (1969). Economic Development with Unlimited Supply of Labor. In A. Agarwala \& S. Singh (Eds.), The Economics of Underdevelopment (pp. 400-499). London, Oxford, New York: Oxford University Press. (Original work published in 1954).

Lipton, M. (1968). Strategy for Agriculture: Urban Bias and Rural Planning. In P. Streeten \& M. Lipton (Eds.), The Crisis of Indian Planning: Economic Planning in the 1960s (pp. 83-147). London: Oxford University Press. 
Lodefalk, M. (2013). Servicification of manufacturing: evidence from Sweden. International Journal of Economics and Business Research, 61), 87-113. https://doi.org/10.1504/IJEBR.2013.054855

Mccombie, J., \& Thirlwall, A. (1994a). The Balance-of-Payment constraint as an explanation of international growth rates differences. New York: ST Martin's Press.

Mccombie, J., \& Thirlwall, A. (1994b). Economic growth and the balance-ofpayments constraints. New York: ST. Martin's Press.

Mckinsey \& Company (2012). Manufacturing the future: the next era of global growth and innovation, New York: McKinsey Global Institute.

Mikesell, R. F. (1997). Explaining the resource curse, with special reference to mineral-exporting countries. Resources Policy, 23(4), 191-199. https://doi.org/10.1016/S0301-4207(97)00036-6

Miller, R. E., \& Blair, P. D. (2009). Input-Output Analisys: Foundations and Extensions (2nd ed., Vol. 1). Cambrige: Cambridge University Press. https://doi.org/10.1017/CBO9781107415324.004

Moreno-Brid, J. C. (2003). Capital Flows, Interest Payments and the Balance-ofPayments Constrained Growth Model: A Theoretical and Empirical Analysis. Metroeconomica, 54(2-3), 346-365. https://doi.org/10.1111/1467-999X.00170

Nordås, H. K., \& Kim, Y. (2013). The Role of Services for Competitiveness in Manufacturing, OECD Trade Policy Papers (148). OECD Publishing, Paris. https://doi.org/10.1787/5k484xb7cx6b-en

OECD (2005). Growth on services: Fostering Employment, Productivity and Innovation. The Organization for Economic Co-operation and Development (OECD), France.

Palma, G. (2005). Four sources of "de-industrialization" and a new concept of the "dutch disease." (J. A. Ocampo, Ed.), Beyond reforms: structural dynamics and macroeconomic vulnerability. Palo Alto, CA; Washington, DC: Stanford University Press and The World Bank. https://doi.org/10.1596/978-0-8213-5819-7

Prates, D. (2006). A inserção externa da economia brasileira no governo Lula. In R. Carneiro (Ed.), A Supremacia dos Mercados e a Política Econômica do Governo Lula. Sao Paulo: Editora UNESP publishing house. 
Prebisch, R. (2000). O desenvolvimento econômico da América Latina e seus principais problemas. In R. Bielschowsky (Ed.), Cinquenta anos de pensamento na CEPAL (1st ed., pp. 69-136). Rio de Janeiro: Ed. Record. (Original work published in 1949)

Rasmussen, P. (1956). Studies in Intersectoral Relations. Amsterdam: North Holland.

Rocha, I. (2011). Reestruturação industrial no Brasil: uma análise da dinâmica comercial e produtiva da economia (Mphil Dissertation). Instituto de Economia, Universidade Estadual de Campinas. Retrieved from http://bdtd.ibict.br/vufind/Record/CAMP_b0c2a3a0ac456006c3d57452c6 f47c94

Rodrik, D. (2007). Industrial development: Some stylized facts and policy directions. In Industrial Development for the 21st Century: Sustainable Development Perspectives (pp. 7-28). New York: Division for Sustainable Development, United Nations.

Rosenstein-Rodan, P. N. (1943). Problems of Industrialisation of Eastern and SouthEastern Europe. The Economic Journal, 53(210/211), 202. https://doi.org/10.2307/2226317

Rostow, W. (1960). The stages of growth: A non-communist manifesto. Cambridge: Cambridge University Press.

Sachs, J. D., \& Warner, A. M. (2001). The curse of natural resources. European Economic Review, 45(4-6), 827-838. https://doi.org/10.1016/S00142921(01)00125-8

Schultz, T. (1964). Transforming traditional agriculture. New Haven, CT: Yale University Press.

Singer, H. (1950). The distribution of gains between investing and borrowing countries. American Economic Review, 40(2), 473-485.

Szirmai, A. (2012). Industrialisation as an engine of growth in developing countries, 1950-2005. Structural Change and Economic Dynamics, 23(4), 406-420. https://doi.org/10.1016/j.strueco.2011.01.005

Tavares, M. (1998). Ciclo e crise: o movimento recente da industrialização brasileira (Coleção 30 anos de Economia). Campinas: IE/Unicamp.

Thirlwall, A. P. (2004). The balance of payments constraint as an explanation of international growth rate differences. In J. S. L. McCombie \& A. P. 
Thirlwall (Eds.), Essays on Balance of Payments Constrained Growth (pp. 39-45). London: Routledge.

Thirlwall, A. P., \& Hussain, M. N. (1982). The balance of payments constraint, capital flows and growth rate differences between developing countries. Oxford Economic Papers, 34(3), 498-510. https://doi.org/10.1093/oxfordjournals.oep.a041565

Timmer, M. P., de Vries, G. J., \& de Vries, K. (2015). Patterns of Structural Change in Developing Countries. In J. Weiss \& M. Tribe (Eds.), Handbook of Industry and Development (pp. 65-83). Routledge.

Timmer, M. P., Dietzenbacher, E., Los, B., Stehrer, R., \& de Vries, G. J. (2015b). An Illustrated User Guide to the World Input-Output Database: the Case of Global Automotive Production. Review of International Economics, 23(3), 575-605. https://doi.org/10.1111/roie.12178

UNIDO - United Nations Industrial Development Organization (2012). UNIDO Annual Report 2012. Vienna: United Nations.

Verdoorn, P. J. (1949). On the factors determining the growth of labour productivity. In Italian Economic Papers (pp. 45-53). Oxford: Oxford University Press.

World Bank (2014). World Development Indicators (WDI). Washington: World Bank. Retrieved from http://datatopics.worldbank.org/worlddevelopment-indicators/ 